\title{
READING STRATEGIES AS DEVELOPMENT MODEL ENGLISH COGNITION OF SENIOR HIGH SCHOOL STUDENTS
}

\author{
Supeno', Imam Suseno², Lubban Anwari Alhamidi ${ }^{3}$ \\ Indraprasta PGRI University Jakarta, Indonesia \\ ('supeno919@yahoo.com, ${ }^{2}$ susenoblr@gmail.com, ${ }^{3}$ lubbanalhamidi@yahoo.com)
}

Received: $10^{\text {th }}$ April 2017; Revised: $20^{\text {th }}$ May 2017; Accepted: $20^{\text {th }}$ June 2017

\begin{abstract}
This study aims to develop a model of reading strategies of English language learning which is expected to further enhance students' cognitive abilities in English. The model reading strategies serve as a strategy to read the English subtitles via bottom-up, top-down and mixed strategies that are capable of triggering the students' critical thinking and have been integrated with development ideas from experts and linguists. The study employed a cluster random sampling of 30 schools and 900 students for the standardization of the model reading strategies as a new model that best enhance the cognitive power of English language learning. The method used was Research and Development, through seven steps in the research cycles. The subjects were high school students in the class ten ${ }^{\text {th }}$ in Special Capital Region of Jakarta. The steps to reading development strategy that are able to improve the cognitive of students are 6 steps consisting of: overall understanding, understanding on contextual meaning, assumption of contextual meaning, look for meaning in contextual output, searching for further meaning, and returning to the main idea of our thinking.
\end{abstract}

Key Words: reading strategies; cognition; ability

\begin{abstract}
ABSTRAK
Penelitian ini bertujuan mengembangkan model pembelajaran bahasa Inggris yakni reading strategies, yang diharapkan dapat meningkatkan daya kognitif bahasa Inggris siswa. Permodelan reading strategies sebagai strategi untuk membaca teks bahasa Inggris melalui strategi bottom-up, top-down dan mixed yang mampu memicu pemikiran kritis siswa dan telah diintegrasikan dengan gagasan pengembangan dari para ahli dan ahli bahasa. Dengan cluster random sampling terpilih sebanyak 30 sekolah dan 900 siswa untuk standarisasi model reading strategies sebagai model baru yang dapat meningkatkan daya kognitif bahasa Inggris siswa. Metode yang digunakan adalah Research and Development, melalui tujuh langkah dalam siklus penelitian. Subjek penelitian adalah siswa SMA di kelas sepuluh di DKI Jakarta. Hasil penelitian menunjukkan bahwa reading strategies yang dapat meningkatkan kemampuan kognitif siswa yaitu melalui adalah 6 langkah strategi membaca yaitu: pemahaman teks secara utuh, memahami makna dalam konteks, berpikir dan menduga tentang makna, mencari makna dalam konteks, mencari makna lebih jauh, dan kembali pada pemikiran makna kata.
\end{abstract}

Kata Kunci: strategi membaca; kognitif; kemampuan

How to Cite: Supeno. Suseno,I. Alhamidi, L. A. (2017). Reading Strategies as Development Model English Cognition of Senior High School Students. IJEE (Indonesian Journal of English Education), 4(1), 84-96. doi:10.15408/ijee.v4i1.4822. 


\section{INTRODUCTION}

Reading strategies is a skill to look for information in terms of speaking ability. (2000) suggested that reading is one of the basic skills of language which has a complex activity included in it, such as thinking, filtering information and interpreting the meaning. Reading comprehension is a skill acquisition generalized knowledge, which allows people acquire and realize the information obtained as a result of reading the written material.

Reading is a mental activity to understand what the other party told through the medium of writing. Reading comprehension is a process to understand the content of reading, looking for relationships between terms, causality, the differences and similarities between the case in the discourse. Reading comprehension is not a wonderful reading, but reading to know or find the idea either express or implied.

Correspondingly, Goodman (2002) saw reading as a linguistic process, in the sense that it originated from the coded surface representation language and ends with the meanings constructed. By reading one can know the meaning contained hereinafter gain an understanding of a reading, the reader should take advantage of the information they already had, the information obtained during his life, the result of previous readings, and other information sources. Perfection reading results can be achieved, if the reader is able to relate new information contained in the text with a background or knowledge belonged to it.

Complex process occurs in reading because of the demands of the reader able to integrate critical thinking skills, analytical, and knowledge held within the context of the situation presented meaning of reading material. The ability of combining letters into words is part of reading. In addition, the reader understands the reading does not need to identify the word-by in the reading but finding meaning from the text. By reading comprehension process will occur. Reading comprehension as a process that occurs between the reader to read the text in an event. Reading activities geared towards mastering the content of reading. Readers should be able to master and understand the literature they read. Elements that should be present in every act of reading is comprehension. Reading comprehension is a set of skills for gaining knowledge, which allows people acquire and realize the information obtained as a result of reading the written language. 
Reading is seen as an event communication between the sender and the recipient. Reading is a form of communication. Information and ideas were exchanged between the writer and the reader in the act of communication. The meaning is communicated and interpreted by the reader writer is reviewed, to understand the meaning of the text in detail, the reader should have a good understanding of the meaning of pragmatic manner.

Reading is a mental process that requires the reader to follow and understand the message from the author that much in terms of place and time. Good readers think are active reader in the reading process, often predict what will happen later. Type these readings using the skill in predicting, reason, question, and concluded to understand the meaning contained in the text reading. Readers who have the reasoning ability as well will be able to advance understanding in reading especially when the reader has entered into an understanding associated with predicting the meaning of vocabulary based on the reading text.

The 1945 Constitution
(Amendment versions), Article 31,
paragraph 3 states, "the government
shall manage and organize a national
education system, which enhances faith
and piety and good character in the

context of the intellectual life of the nation, which is regulated by law". Further, in Law No. 20/2003 Article 5, states that every citizen has an equal right to obtain a quality education, citizens who have physical, emotional, mental, intellectual, and/or social entitled to special education, citizens in remote or underdeveloped as well as remote indigenous communities the right to obtain special education services, citizens who have the intelligence and special talents are entitled to special education as well as every citizen is entitled to increase the chance of lifelong education.

Procedural model reading strategies are most effective when it can generate creative and critical thinking of students so that students can improve their cognition. Paying attention to these issues, related to the development model of learning English through reading strategies is an urgent step to be implemented. Step model of reading strategies is to formulate procedures that can evoke more critical thinking of the students. When a model of reading strategy can be absorbed, understood and applied properly, the student's cognitive power can be optimized.

The scope of this study is students of senior high school in Jakarta. The sample was taken through 
the sampling method purposive 5 schools; the technique of sampling is set based on certain considerations of researchers to carry out trials a model reading strategies formulated on a small scale so that not more than 30 schools and 900 students a representative number of samples to be used in the form standardize learning model reading strategies that best enhance the cognitive power of English high school students in Jakarta. The goals of the study are: 1) Developing an evaluation model of the procedural reading strategies in English through the button-up, top-down and mixed strategies that could stimulate students to think more critically and dynamically at the time when they read the English subtitles.; 2) To further enhance the cognitive power of the ten ${ }^{\text {th }}$ grade English high school students' in Jakarta through the implementation of reading strategies using the second pattern. The results of the study are a model then the results of the evaluation and development of learning English through reading strategies first in order to improve the cognitive power of English students at SMA (High School) in Jakarta through the application of a second model, the pupils will have the ability and cognitive power qualification so far would be more better than ever.; 3) The results of this study are also expected to influence government policy in order to improve the professionalism of teachers in Jakarta as well as a positive input to the principals, supervisors, Head of Jakarta Education Department and the Head Office of the Ministry of Religious Jakarta on methods of learning reading strategies in English.

Types of data collected in the study was a qualitative and quantitative data. Qualitative data is data narrative results of interviews and field observations that contains procedural information or implementation stage that is designed to systematically modeling reading strategies that are meant researchers and students respond well when the process or after participating in learning activities. On the contrary, quantitative data obtained from the the post-test for analysis of comparative data to measure quantitatively modeling the successful implementation of reading strategies.

\section{Reading Strategies}

The word "strategy" is derived from the Greek word, Strategos who was a 'military commander' at the age of Athenian democracy. Strategy is an overall approach regarding to the implementation of the idea, planning, and execution of an activity within a certain time. It contains a good strategy to have a theme, identifying the 
contributing factors in accordance with the principles of the implementation of the idea of a rational, efficient in funding, and have the tactics to achieve goals effectively. The difference meaning of strategy from tactics are in the scope seems to be either narrower or shorter time. However, people generally often feel confused to differenciate the meaning of the two words.

There are several strategies for reading that can be used to enhance students' understanding, which includes, metacognitive strategies, cloze procedure, and the question guide (Kartadinata, 2006). (1) Metacognitive Strategies: Metacognitive related to a person's knowledge on the use of the intellectual brain and conscious effort to monitor or control the use of the intellectual abilities. These include the occurrence of any metacognitive thinking. Part metacognitive process determining what tasks needed to gain understanding. Readers need to ask: a). Is the answer that I need to express directly ?, b). Is the text expressing answer with a clear signal that helps decide the answer is clearly, c). Is the answer should be associated to the story?; (2) Cloze Procedure: Cloze procedure of use also to improve understanding by eliminating some of the information in the readings and students were asked to fill it. In the execution of cloze procedure involves the removal of the letter, syllable, word, phrase, clause or sentence. Cloze procedure can be used by teachers to teach reading skills, not to the test.; (3) Guiding Question: During the reading, guiding questions are often used to enhance understanding. Students can be trained to remember the facts in a way change the fact that the question "why". Questions may be submitted by the teacher guides the student or student's submitted himself while reading.

Meanwhile, according to Klein (in Jauharoti, 2009) reading strategies include Bottom-Up, Top-Down, and Mixed strategies. (1) Bottom-Up Strategy: This strategy is generally used at the beginning of classlearning, and is also used to understand the text that has a high degree of difficulty. The difficulties encountered could be a matter of language, can also be about the content of the text. And methods used in this strategy is to use the method of spelling.; (2) Top-Down Strategy: Strategy Top-Down is the opposite of the strategy of Bottom-Up, backgroundknowledge becomes a variable that is very important, because here students learn to read in a high level. Background knowledge possessed by students is very helpful in understanding the text for it should be in choosing reading texts adapted to the 
level of knowledge and student residence. (3) Mixed Strategy (mix): a combination of execution strategies Bottom-Up and Top-Down to cover the shortfall from the previous two strategies in the implementation of the field. A teacher should not only use one strategy. Teachers can choose any strategy that can be applied in the teaching of reading and its use can be performed simultaneously, which is called a mixed strategy.

\section{Cognitive Power}

An understanding of the dimensions of cognitive processes will help teachers to differenciate the thought process that are achieved by learners in a learning process. Having regard to cognitive processes will be more accurate in determining the level of thinking that will be built as a result of the learning process to be performed. Dettmer (2006) classified dimension of cognitive processes into eight levels of thinking, i.e knowledge (C1), comprehension (C2), application (C3), analysis (C4), evaluation (C5), synthesis (C6), imagination (C7), and creation (C8). This dimension is a continuum. The explanation of each level of thinking is explained as follows:

C1. Knowledge (Know): The memory is also called the knowledge (knowledge). Given the ability to regain knowledge relevant to long- term memory. Two words are worth remembering is recognizing and recalling. Recognition is the ability to find information on longterm memory that is relevant to the information presented. While recalling is the ability to recall information from long-term memory in response to the problem. Knowledge that is stored in the memory is dug in as needed through the shape memory recall (recall) or know back (recognition). Knowledge is the cognitive aspects of the lowest and most basic.

C2. Understanding (comprehend): Understanding that understand the material or ideas given. Meanwhile, according to Winkel (2004) Understanding is the ability to grasp the meaning and significance of the material being studied. The existence of this ability can be seen in the form of the ability to describe the content of the subject of a discussion, the ability to change the data presented in some form to another form. Comprehension is also called to understand and in English is called learning concept, which means that when teachers deliver lessons, the students must make an idea of the content of the lesson. The description is given in a way that gradually the lessons delivered 
picture is formed in the minds of students. Work performed learners think at this stage just to sort and organize the information. Bloom stated that a learner is said to have an understanding when confronted with something that should be communicated, he knows what to communicate either verbally or in writing or in the form of verbal and symbolic and can use the ideas.

C3. Application (Apply): Application is a cognitive process of how to apply a concept, principles and methods on a problem and new concrete. Their thought process is stated in the application of a concept that has never faced the problem or the application of a method of working on solving new problems. Measurement capability is generally used approach to problem solving (problem solving).

C4. Analysis (Analyze): Analysis is the process of thinking to elaborate a whole into parts so that the overall structure or organization can be well understood. Their thought process is stated in the analysis of the principal parts or components of the base, along with parts of the relationship. Capabilities are often matched by the analysis is the ability to distinguish (differentiating) and organizing (organizing). Differentiating includes the ability to distinguish the parts of the overall structure in the appropriate form. Organizing includes the ability to identify the elements together into structures that are interrelated. Analytical capabilities are classified into three groups, namely: 1) Analysis of the Elements, 2) Analysis of Relationships, and 3) Analysis Principles.

C5. Evaluation (Evaluate): evaluation or assessment which gives due consideration to the value of the materials or methods for a particular purpose. With the ability to evaluate the learner is expected to make a consideration of a statement, concepts, situations and so forth based on certain criteria. The most important element in the evaluation is to create the conditions such that learners develop criteria, standards or measures to evaluate something.

C6. Synthesis (synthesize): Synthesis is the ability to form a coalition or a new pattern. The parts are connected to each other, so as to create a new form. This capability is one level higher than the analytical skills, because the required criteria to find a pattern and organizational structure. For 
example, learners can formulate a research hypothesis is based on the theory and the study of specific data. Synthesis one level above analysis, someone at the synthesis level will be able to explain the structure or pattern of a scenario not previously seen, and is able to recognize the data or information that should be obtained to produce the required solution.

C7. Imagination (Image): Imagination is the ability to collect all the energy to achieve the goal. Einstein has proved this by being able to produce so many spectacular original theory only begins with an imagination. So we can say that imagination is energy. The energy that is processed continually be manifested in what we imagine. In the daily life too, this visualization technique can be done by imagining positive things that exist in our goals.

C8. Creativity (Create): Creativity means of creativity, the ability to invent or create something new. Creating is holding something new that never existed before. According Munandar(in Purwanto, 2005: 511-512), a new sense of creativity that does not mean the result of copyright did not exist, but a combination of something that never was into something new. Creativity can be broadly viewed as a personality, the results and the process. Creativity is the mental ability and various types of typical human skills that can give birth to disclosure of unique, different, original, totally new, beautiful, efficient, effective and appropriate. As examples of the formulation of indicators of competence that corresponds to this level is like "the learner is able to make a map of the concept of civic duty". The verb "make" including cognitive processes "creativity."

\section{METHOD}

This study is a follow up of the results of the development of model reading strategies in earlier years that the output of research, ideas and inputs of reference can be used for students, teachers of English, and English language experts. Based on the study concerning with the model of reading strategies were developed based on the top-down strategy. The top-down reading strategies are then aligned logically, studied more in depth as well as communicated with some linguists to get feedback, to get a reading model of top-down development strategy. The model was then tested in the field with 
a small sample and as a result, there is an increase in cognition.

Development of the model reading strategies will be enhanced by preparing a larger scale trials, especially for high school students in the tenth grade at Special Capital Region of Jakarta. The research was conducted in , 2016 and 2017. The participants of this study are the high school students, both from the state and private education institutions in the region of Jakarta.

As for the analysis of qualitative data in the form of data reduction, data display and verification. As HusainiUsman (2004), stated that 1) Reduction of data, meaning the data that has been collected from the field and documented that there is in turn simplified and adapted to the focus of this study, 2) Display data, which formulates the data in the matrix / graph, and thus avoided from the landfill without the categories of data and avoid overlap of data, 3) Taking conclusion and verification, which is to determine patterns, models, and equations to be concluded. In this step necessary efforts categorization of data by theme or sub-themes discussed. By means of verification is expected to make it easier to pass the analysis, and in turn facilitate researchers to draw conclusions as research findings.

Cognitive processes that teachers will assist learners in thinking procces to reach the goal of learning so that teaching and learning will take place optimally. Besides understanding of cognitive processes will assist teachers in preparing the formulation of an explicit learning objectives more accurately. Having regard to cognitive processes will be more accurate in determining the level of thinking that will be built as a result of the learning process to be performed. In improving the students 'cognitive need for appropriate strategies to improve students' cognitive power.

So the results of the analysis of qualitative data taken are arranged in such a way that support or provide information about the advantages and disadvantages of the methods of learning reading strategies. While quantitative data that have been collected from the results of the objective tests of students, then interprated with descriptive analysis, and then tested the requirements analysis before tested a level of significance by the $t$-test in the form of normality test to look at the distribution of data normality and homogeneity to obtain information similarity variance 
between groups of students from some schools that became the object of a test model of learning.

Figure 1: Research Flow Chart

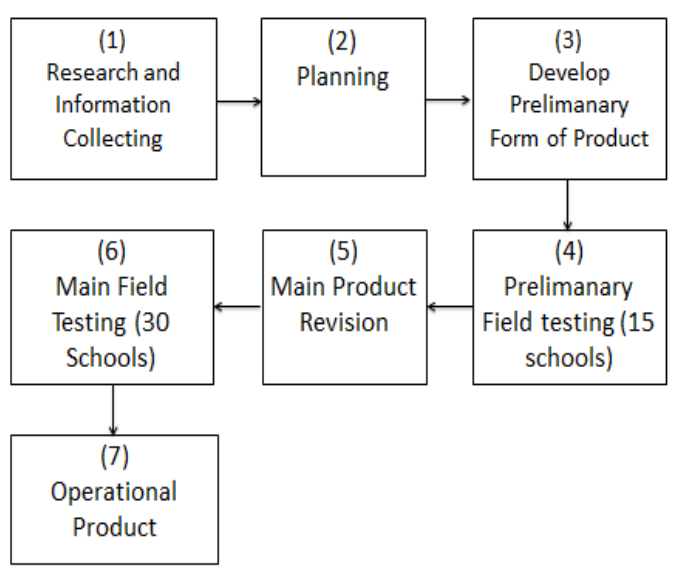

Resources : Adapted from Borg and Gall (1983: 775)

\section{CONCLUSION AND DISCUSSION}

\section{FINDING}

Based on the interview with the English teacher, thetendency of students in reading English texts is to use a top-down strategy of reading. The steps of top-down reading strategies development results are as follows Figure 2.

Figure 2 shows the six steps strategic reading English texts that students can use. Reading strategies development once taught a class of students learning English, then held the English language text reading test by asking a question that is graded based on the cognitive level set by the researchers.

Figure 2: Development Reading Strategy

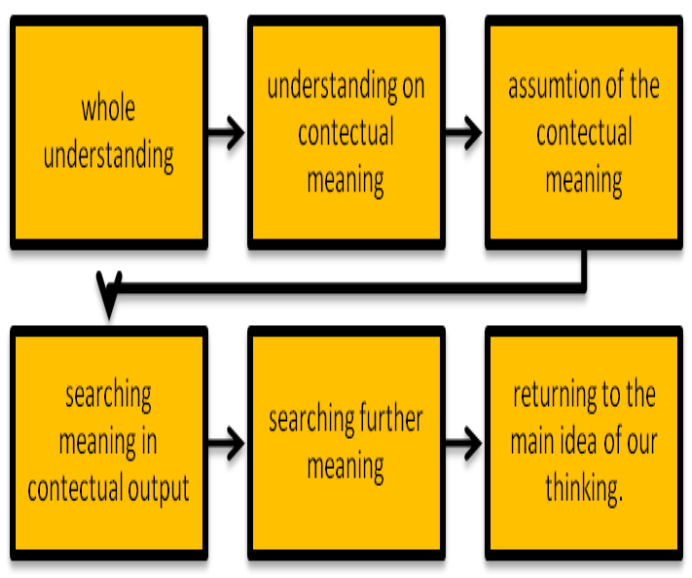

Figure 2 shows the six steps strategic reading English texts that students can use. Reading strategies development once taught a class of students learning English, then held the English language text reading test by asking a question that is graded based on the cognitive level set by the researchers.

The rationalization of the operation of the six-step strategy of reading English texts proves to make it easier for the reader (student) to derive the meaning contained in the English text in question. Beginning with the first step the text reader understands the full text based on the ability to mean not to read / interpret each word in one sentence, then the second step readers understand the meaning in the context, 
interpreted text readers know quite a few keywords to understand the meaning in the text. the third step readers suspect the meaning contained in the text, the alleged meaning comes because the reader knows the keyword in the text. The fourth step readers look for meaning in context, meaning reader think clearly and not hastily determine meaning in context, step of reader look for meaning further and last step six reader return to thinking meaning of word to get meaning of text correct and intact.

Six steps reading strategy is a strategy that intact and simultaneously work quickly. So the implementation is needed habituation, because the six steps are not broken / stopped in the first step or mid. So more often applied to the English lesson, making students accustomed to apply it and facilitate students to find the meaning of the English text they read. The role of English teacher becomes very important to guide and familiarize the use of the English text reading strategy. Teachers teach with interactive that is continuing to assist students in understanding the contents of reading English text. Because understanding the meaning in the English text requires a fairly unique language intelligence. For students who like English lessons and accustomed to reading English text would be easy / quick to capture text messages because it has a high learning motivation. Conversely for students who are motivated to learn low (the mastery of vocabulary, grammar, etc.) the need for more intensive assistance and habituation in implementing strategies to read English text.

\section{DISCUSSION}

The results of six steps implementation of the reading strategies to the students from the research schools'partners, and then held a reading test of English texts to measure cognitive abilities obtained the result described in the form of percentage of students who success to answer the questions.

The obtained results' proportion of correct answers as follows:

Figure 3: Cognitif's ability both pre-test and post-test.

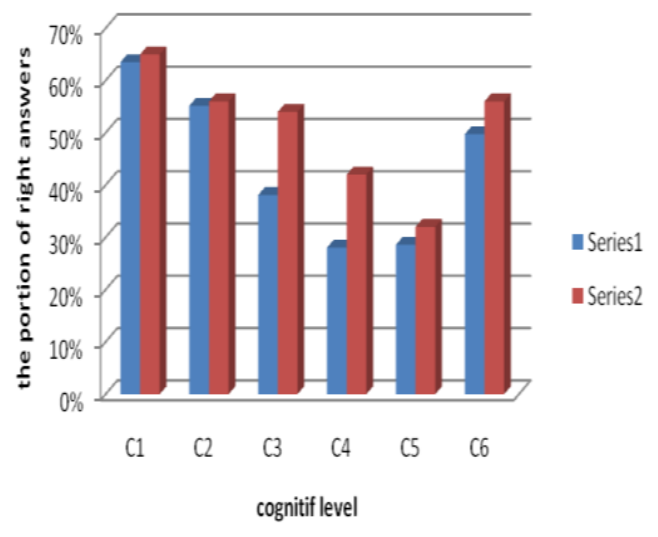


The implementation of the sixstep reading strategy developed by researchers has been shown to improve students' cognitive abilities in understanding English texts. This is shown in Figure 3 where the cognitive abilities of the pre-test (before the introduction of the latest reading strategy) and post-tests after the application of the reading strategy through the six tactical steps, are seen at all cognitive levels improved.

The cognitive enhancement process of reading English text by teachers through the application of a six-step reading strategy helps students in the process of thinking quickly finding meaning from English text. Hence, the goal of learning English can be achieved optimally. English teachers can improve understanding of the cognitive processes of students, it helps in formulating explicit formulations of more accurate English learning objectives.

By taking into account the different levels of cognitive abilities of students, teachers need to be more careful in providing the frequency of mentoring and habituation in the application of the six-step strategy of reading English subtitles. So by observing the cognitive level of reading the students' English text more carefully, the teacher is able to determine the achievement level of thinking/cognitive that will be developed more optimally. In improving students 'cognitive power, there needs to be an appropriate strategy to improve students' cognitive ability from reading English text. The implementation of the six-step strategy of reading formulated English text proved to be able to improve students' English cognitive abilities.

\section{CONCLUSION AND SUGGESTION}

After carefully revised the product, then enters the sixth stage is a major test with scale research subjects were the 30 schools with 30 students per school, is also possible in the test analysis carried out by comparing the control group. Quantitative data used in the comparative analysis of data from the activities of pre-test and posttest. The results of the analysis were assessed on the basis of the achievement of educational goals and compared with the control group.

Stage seven results of trials on the scale was subsequently revised to product operations. During the trial the development of the model both in the early phase and the phase-scale trials were researchers will conduct random interviews to students, observation and data analysis of qualitative as well as quantitative. The results of the data 
analysis complement the results of the new modeling that has been run through two trials both the small scale and medium scale.

In the eighth stage results from a revised reading strategies modeling product continued on a large scale test involving 30 secondary schools that are in the environment of Jakarta and surrounding areas, to ensure that regional differences do not become a major factor differences in product yield modeling. This next stage of modeling Nine will the last revision of reading strategies and tenth stage is part of the Dissemination and implementation of the new model reading strategies.

Implementation of the Phase 2 study year is expected to produce a model of strategic reading that can improve the cognitive abilities of high school students in Jakarta. The output of the Phase 2 study will be included in international seminars and published in accredited national journals.

\section{REFERENCES}

Dettmer, P. (2006). New blooms in established fields: Four domains of learning and doing. Roeper Review; Winter 2006; 28, 2; ProQuest Education Journals.

Early, M., \& Ericson, B. O. (2003). The act of readingIn L. M. Cleary and M. D. Linn, Linguistics for teachers. New York: McGraw-Hill.

Goodman, K. S. (2002). The reading process, interactive approaches to second language eading, ed. Patricia L. Carrell, Joanne Devine and David E. Eskey. Cambridge : University Press.

Purwanto. (2005). Kreativitas berpikir dan perilaku dalam tes. In Jurnal Pendidikan dan Kebudayaan, 55(11), Juli, 2005.

Santrock, J. W. (2000). Life-span development. USA: Times Mirror Higher Education Inc.

Winkel, W.S. (2004). Psikologi pengajaran. Yogyakarta: Media Abadi. 